\title{
Perancangan Sistem Informasi Stok Barang Terpadu pada Toko Handphone di Pasar Singosaren Surakarta
}

\author{
Sukadi ${ }^{1}$, Diana Rendrarini ${ }^{2}$ \\ Fakultas Teknik, Universitas Merdeka Madiun, Jl. Serayu No. 79, Madiun, 63133 \\ E-mail: sukadi@unmer-madiun.ac.id \\ Fakultas Teknik, Universitas Merdeka Madiun, Jl. Serayu No. 79, Madiun, 63133 \\ E-mail: dianarendra72@gmail.com
}

\begin{abstract}
Singosaren Market or also known by the people of Surakarta City and its surroundings with Matahari Singosaren is one of the centers of Mobile Phones or Smartphones in Surakarta City. Singosaren Market was first built in 1988, at first the first floor was clothing stalls but starting in $\mathbf{2 0 0 0}$ the first floor was changed to a mobile shops. Mobile phone sellers in their daily lives if there are buyers who want to buy goods and the seller of the stock is empty, then the sellers will ask other sellers whether the stock is still there or empty. To speed up or help sellers get information on which stores are not empty, in this study a Integrated Inventory Information System Design for Mobile Stores in Singosaren Market Surakarta was designed, which is expected to be applied in the future at mobile shops in Singosaren Market Surakarta.
\end{abstract}

Keywords—: Goods Stock; Mobile; Singosaren Market.

\section{PENDAHULUAN}

Handphone atau smartphone saat ini sudah menjadi kebutuhan pokok dalam berkomunikasi bagi sebagaian besar penduduk Indonesia. Pada tahun 2017 pengguna handphone di Indonesia mencapai 371,4 juta pengguna atau sekitar 142 persen dari total jumlah penduduk Indonesia. Dimana artinya setiap penduduk Indonesia rata-rata mempunyai handphone sebanyak 1,4 buah. Dibandingkan pada bulan Januari 2016, pengguna handphone di Indonesia meningkat 14 persen.

Seiring dengan laju pengguna handphone yang sangat tinggi maka tidak heran pula jika bisnis handphonepun meningkat dengan pesat pula, terutama perdagangan atau jual beli handphone. Salah satunya adalah di kota Surakarta yaitu di Pasar Singosaren, yang mana lantai 1 menjadi salah satu pusat jual beli handpphone di kota Surakarta. Akan tetapi banyaknya penjual dan juga pembeli belum diimbangi dengan sistem informasi (terutama stok barang) yang mendukung kegiatan jual beli tersebut. Di pasar Singosaren para penjual handphone dalam kesehariannya jika ada pembeli yang ingin membeli barang dan penjual stok barangnya kosong, maka para penjual akan menanyakan ke penjual lain apakah stok masih ada atau tidak. Untuk mempercepat atau membantu penjual mendapatkan informasi toko mana yang stok barangnya tidak kosong, maka perlu dibuat sistem informasi stok barang terpadu untuk para penjual handphone di pasar Singosaren Surakarta.

Penelitian yang dilakukan oleh Dessy Julyanti dan Trisnadi Wijaya yang berjudul “Analisis Sistem Informasi Akuntansi Persediaan Barang Dagang pada Mega Phone Store" dijelaskan bahwa Mega Phone Store masih belum mempunyai sistem informasi akuntansi persediaan barang dagang yang efektif. Hasil ppenelitian menunjukkan bahwa Mega Phone Store memerlukan adanya perbaikan berupa pemisahan gudang antara barang retail dan grosir serta perubahan dari sistem lama ke sistem baru dengan memanfaatkan program Accurate.

Penelitian yang dilakukan oleh Ujang Mulayana dan Dian Gustina yang berjudul "Perancangan Sistem Penjualan Handphone Berbasis Web pada Toko Ilham Cellular Jakarta" dijelaskan bahwa untuk meniingkatkan keakuratan data pada pencatatan dan pengolahan data barang diperlukan pembangunan sistem informasi penjualan barang yang terkomputerisasi.

Penelitian yang dilakukan oleh Rudi Harianto yang berjudul "Sistem Informasi Ketersediaan Stok Handphone Menggunakan Metode Double Exponental Smoothing (Studi kasus di Edyta Cell)" dijelaskan bahwa sistem ketersediaan stok handphone menggunakan metode Double Exponental Smoothing pemilik toko akan lebih mudah menghitung peramalan ketersediaan stok handphone dengan mengacu data penjualan sebelumnya.

Berdasarkan uraian tersebut maka dalam penelitian itu dibuat sebuah perancangan Sistem Informasi Stok Barang Terpadu pada Toko Handphone di Pasar Singosaren Surakarta yang ke depannya diharapkan dapat diaplikasikan ke dalam sistem informasi sehingga dapat memudahkan bagi penjual handphone dalam mencari barang dagangan ke penjual yang lain.

\section{METODE PENELITIAN}

Metode penelitian yang digunakan yaitu Metode Penelitian Studi Kasus, dimana kontak dengan subyek penelitian dilakukan dalam menghimpun data/informasi untuk penelitian.

Sedangkan untuk Pengumpulan Data menggunakan metode :

\section{A. Observasi}


Observasi adalah mengumpulkan data dengan cara mengadakan pengamatan langsung terhadap obyek yang akan diteliti, dalam hal ini peneliti melakukan observasi ke Pasar Singosaren Surakarta.

\section{B. Studi kepustakaan}

Studi kepustakaan digunakan dalam melengkapi teori-teori yang digunakan dalam pembuatan laporan, yaitu dengan menggunakan buku literatur yang berkaitan dengan permasalahan yang dibahas dan juga internet.

\section{III.HASIL DAN PEMBAHASAN}

\section{A. Diagram Konteks}

Diagram konteks digunakan untuk menggambarkan aliran data dalam sebuah sistem dan pengolahan data yang dilakukan oleh sistem. Berikut diagram konteks sistem informasi stok barang terpadu toko handphone di Pasar Singosaren Surakarta :

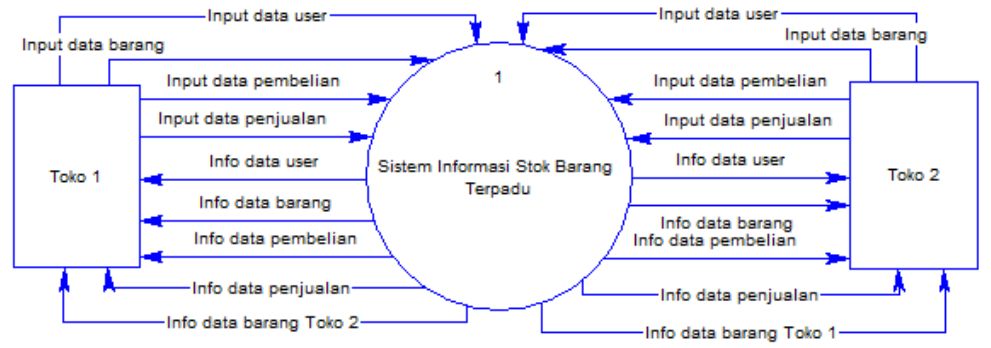

Gambar 1 Diagram Konteks

\section{B. Rancangan Tabel}

a) Table User

Berfungsi untuk menyimpan identitas user.

Jumlah field $: 7$

Primary key : :

b) Table barang

Table 1. Table user

\begin{tabular}{|l|l|c|l|}
\hline \multicolumn{1}{|c|}{ Nama Field } & \multicolumn{1}{c|}{ Tipe Data } & Lebar & \multicolumn{1}{c|}{ Keterangan } \\
\hline Username & Varchar & 15 & Nama user \\
\hline Password & Integer & 15 & Password user \\
\hline Level & Varchar & 15 & Level user \\
\hline Nama_user & Varchar & 25 & Nama pengguna \\
\hline Tgl_Lahir & Date & - & Tanggal lahir user \\
\hline Alamat & Varchar & 30 & Alamat user \\
\hline Telpon & Integer & 13 & Nomor telpon user \\
\hline
\end{tabular}

Berfungsi untuk menyimpan data barang.

Jumlah field : 5

Primary key : Nomor_barang

Table 2. Table barang

\begin{tabular}{|l|l|c|l|}
\hline \multicolumn{1}{|c|}{ Nama Field } & \multicolumn{1}{c|}{ Tipe Data } & Lebar & \multicolumn{1}{c|}{ Keterangan } \\
\hline Nomor_barang & Varchar & 10 & Nomor barang \\
\hline Nama_barang & Varchar & 25 & Nama barang \\
\hline Harga & Integer & 8 & Harga barang \\
\hline Jml & Integer & 3 & Jumlah barang \\
\hline Keterangan & Varchar & 30 & $\begin{array}{l}\text { Keterangan } \\
\text { barang }\end{array}$ \\
\hline
\end{tabular}

c) Table pembelian

Berfungsi untuk menyimpan data barang

Jumlah field : 5

Primary key : nomor_transaksi 
PILAR TEKNOLOGI : Jurnal IImiah IImu-IImu Teknik

Website : http://pilar.unmermadiun.ac.id/index.php/pilarteknologi

d) Table detail pembelian

\begin{tabular}{|l|l|c|l|}
\hline \multicolumn{1}{|c|}{ Nama Field } & \multicolumn{1}{|c|}{ Tipe Data } & Lebar & \multicolumn{1}{c|}{ Keterangan } \\
\hline Nomor_Transaksi & Varchar & 10 & $\begin{array}{l}\text { Nomor transaksi } \\
\text { pembelian }\end{array}$ \\
\hline Tgl & Date & - & $\begin{array}{l}\text { Tanggal } \\
\text { pembelian }\end{array}$ \\
\hline Nama_suplier & Varchar & 25 & Nama suplier \\
\hline Jml & Integer & 3 & Jumlah pembelian \\
\hline Keterangan & Integer & 30 & $\begin{array}{l}\text { Keterangan } \\
\text { transaksi }\end{array}$ \\
\hline
\end{tabular}

Berfungsi uuntuk menyimpan data detail pembelian

Jumlah field : 4

Primary key : nomor_transaksi

Foreign key : nomor_barang

e) Table penjualan

\begin{tabular}{|c|c|c|c|}
\hline Nama Field & Tipe Data & Lebar & Keterangan \\
\hline Nomor_transaksi & Varchar & 10 & $\begin{array}{l}\text { Nomor transaksi } \\
\text { pembelian }\end{array}$ \\
\hline Nomor_barang & Varchar & 10 & Nomor barang \\
\hline Jml & Integer & 3 & Jumlah barang \\
\hline Harga & Integer & 8 & Harga barang \\
\hline
\end{tabular}

Berfungsi menyimpan data penjualan

Jumlah field $: 5$

Primary key : nomor_transaksi

Table 5. Tabel penjualan

\begin{tabular}{|l|l|c|l|}
\hline \multicolumn{1}{|c|}{ Nama Field } & \multicolumn{1}{c|}{ Tipe Data } & Lebar & \multicolumn{1}{c|}{ Keterangan } \\
\hline Nomor_Transaksi & Varchar & 10 & Nomor transaksi \\
\hline Tgl & Date & - & Tanggal penjualan \\
\hline Nama_konsumen & Varchar & 25 & Nama konsumen \\
\hline Jml & Integer & 3 & Jumlah pembelian \\
\hline Keterangan & Integer & 30 & $\begin{array}{l}\text { Keterangan } \\
\text { transaksi }\end{array}$ \\
\hline
\end{tabular}

f) Table detail penjualan

Berfungsi menyimpan data detail penjualan

Jumlah field : : 4

Primary key : nomor_transaksi

Foreign key : nomor_barang

Table 6. Tabel detail penjualan

\begin{tabular}{|l|l|c|l|}
\hline \multicolumn{1}{|c|}{ Nama Field } & Tipe Data & Lebar & Keterangan \\
\hline $\begin{array}{l}\text { Nomor_transaks } \\
\text { i }\end{array}$ & Varchar & 10 & $\begin{array}{l}\text { Nomor } \\
\text { transaksi } \\
\text { penjualan }\end{array}$ \\
\hline Nomor_barang & Varchar & 10 & Nomor barang \\
\hline Jml & Integer & 8 & $\begin{array}{l}\text { Jumlah } \\
\text { penjualan }\end{array}$ \\
\hline Harga & Integer & 3 & Harga barang \\
\hline
\end{tabular}

\section{Rancangan Antar Muka (Form)}

Dalam rancangan sistem informasi stok barang terpadu ini user dibedakan menjadi 3, yaitu :

a) Admin

User Admin mempunyai hak untuk mengonfigurasi sistem.

b) Operator

User operator mempunyai hak untuk melakukan transaksi pembelian dan penjualan

c) Tamu

User tamu mempunyai hak untuk melihat stok barang, dimana user tamu ini merupakan user dari toko handphone yang

lain.

Berikut rancangan tampilan : 
a) Rancangan Form Login

Untuk rancangan form login, untuk semua user sama.

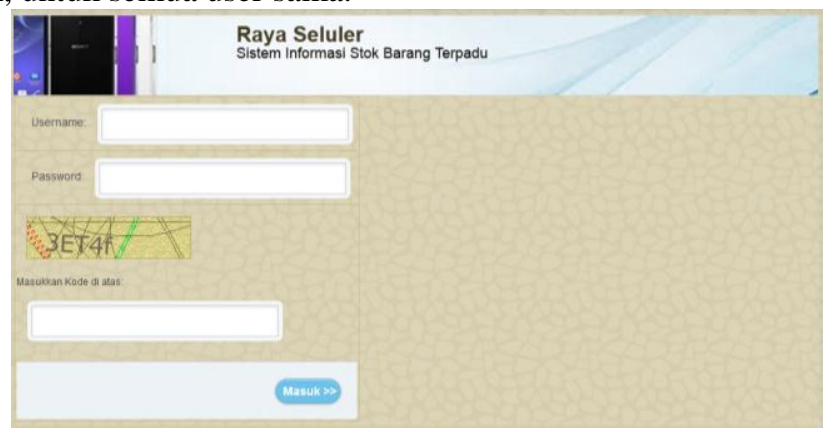

Gambar 2 Rancangan Form Login

b) Rancangan form user admin

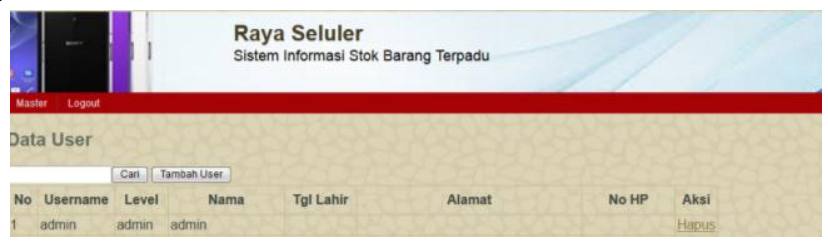

Gambar 3. Rancangan Form user admin

c) Rancangan form user operator

Untuk operator mempunyai 2 hak, yaitu :

i. Input transaksi pembelian
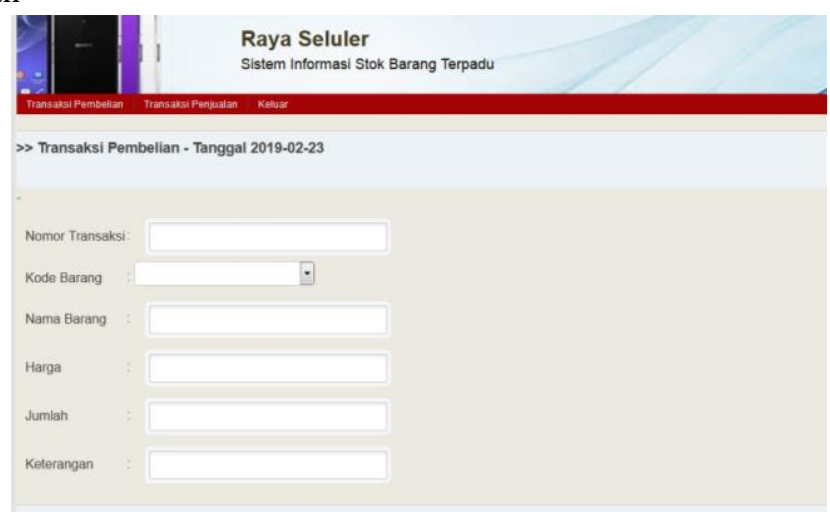

Gambar 4 Rancangan form transaksi pembelian barang

ii. Input transaksi penjualan

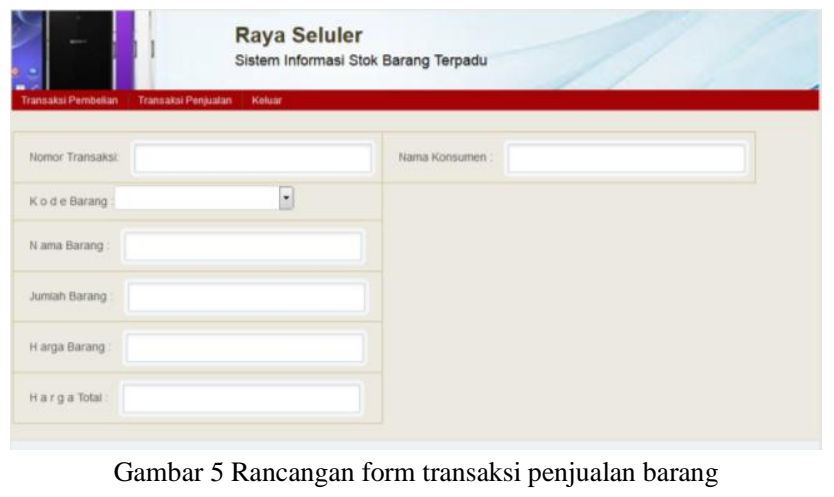

d) Rancangan form user tamu

Untuk user tamu dapat memilih stok barang toko mana yang akan dilihat, kemudian memasukkan Nama Barang untuk melihat stok barang. 


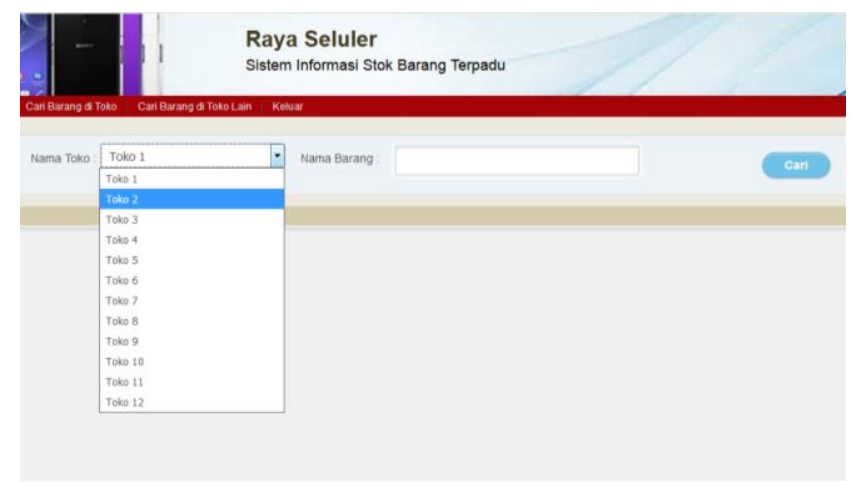

Gambar 6 Rancangan form user tamu untuk pencarian barang di toko lain.

Setelah itu maka akan tampil informasi barang yang dicari.

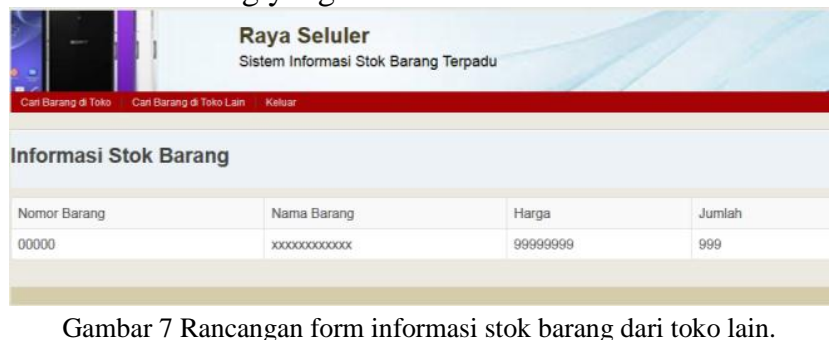

\section{IV.KESIMPULAN}

\section{A. Kesimpulan}

Dari perancangan sistem informasi stok barang terpadu di toko handphone Pasar Singosaren Surakarta dapat diambil kesimpulan bahwa :

a) Perancangan sistem informasi stok barang terpadu ini dapat memberikan gambaran kepada para pemilik toko handphone di Pasar Singosaren Surakarta akan kemudahan dalam pencarian informasi barang.

b) Perancangan sistem informasi stok barang terpadu ini mempunyai fungsi untuk pengolahan data pembelian, penjualan dan juga pengelolaan stok barang.

\section{B. Saran}

Adapun saran untuk penelitian selanjutnya :

a) Perancangan sistem stok barang terpadu ini dapat ditambahkan untuk fasilitas pengembalian barang.

b) Untuk implementasi perancangan sistem stok barang terpadu ini diperlukan Local Area Network atau jaringan Internet.

\section{DAFTAR PUSTAKA}

Harianto R., 2017, Sistem Informasi Ketersediaan Stok Handphone Menggunakan Metode Double Exponential Smoothing (Studi kasus di Edyta Cell), Universitas Nusantara PGRI, Kediri

Julyanti D., Wijaya T., Analisis Sistem Informasi Akuntansi Persediaan Barang Dagang Pada Mega Phone Store, Jurusan Akuntansi, STIE Multi Data Palembang

Laudon, K, C., Laudon, J, P., 2009, Sistem Informasi Manajemen Mengelola Perusahaan Digital, Andi, Yogyakarta

Mulayana U., Gustina D., 2016, Perancangan Sistem Informasi Penjualan Handphone Berbasis Web Pada Toko Ilham Celullar Jakarta, Jurnal Ilmiah FIFO, Volume VIII/No. 2/November/2016, STMIK Nusa Mandiri, UPI YAI

Setyorahayu, E., Sukadi, 2012, Sistem Informasi Pengolahan Data Pasien Rawat Jalan Puskesmas Wonokarto, Seruni FTI UNSA 2012 Volume 1, Hal. 177185, UNSA, Surakarta.

Sukmana F., Sukadi, 2014, Sistem Informasi Pengelolaan Data Barang dan Service Komputer pada Toko Sinar Terang Komputer Pacitan, IJNS - Indonesian Journal on Networking and Security - Volume 3 No 4 - Oktober 2014

Suwartono, Dr., M. Hum., 2014, Dasar-Dasar Metodologi Penelitian, Andi, Yogyakarta

Prosiding, Konferensi Nasional Sistem Informasi, 2009: 4

https://databoks.katadata.co.id

http://pwk.ft.uns.ac.id/pasarsolo/pasar-singosaren/ 